\title{
Visual Language in Japanese Animation
}

\author{
Pitri Haryanti \\ Departement of Japanese \\ Universitas Komputer Indonesia \\ Bandung, Indonesia \\ pitri.haryanti@email.unikom.ac.id
}

\author{
Yeni Nurlatifah \\ Departement of Magister Design \\ Universitas Komputer Indonesia \\ Bandung, Indonesia \\ zofwah@gmail.com
}

\begin{abstract}
The purpose of this research is to find out visual language that appeared in Japanese anime and how it is displayed. This study uses a qualitative approach with descriptive qualitative methods. The data used in this research is anime's frames taken from Japanese animation. As the results of the research, we found out that most of the Wimba in the Japanese anime were minimized and enlarged in order to indicate important things. The main hero position is usually in the middle, there are also positions from left and right or from left to right. The ways of events presented are arranged not to make the audience feel bored. This happened because the Wimba in anime can fill the space and time in the anime frame with a short time.
\end{abstract}

Keywords-Anime, visual language, wimba

\section{INTRODUCTION}

Visual language can be indentified as the fluent application of visual literacy knowledge and techniques in the delivery of a message [1]. Visual language basically has similarity with the textual language. A textual language is a set of strings over an alphabet. The symbols of any sentence are only related to each other by a linear ordering. In contrast, a sentence of a visual language consists of a set of symbols that are, in general, related by several relationships [2].

The term image has a broad meaning, including visible images and imaginary images. In the visual language, the term imagery is equated using the term of 'wimba' [3]. Wimba is the concrete form of the image, which can be seen and touched, which is invisible. There is two part of wimba, the way of wimba dan the contents of wimba. The way of wimba is how the wimba are described, the contents of Wimba are the objects described [4].

In addition to the term wimba, there is also called expression. The expression is divided into two, namely the inner expression in and external expression [5]. The order of expression is a way of arranging various wimba and ways of wimba so that the picture can tell stories. For example, the ostrich drawn is bigger than the hunter who trapped it: the important message in the story is the ostrich, while the humans are less important. While the outer expression is a way to make a difference between the expressions between one picture and the next one strung together in a sequence so that the picture can tell a story.

External expressions can be found in series drawings (reliefs, comics and films). Visual Language is a way of 'reading' pictures, from various images, picture of children, prehistoric cave pictures, wayang beber pistures, then to symbolic images, decorative images and shadow images from shadow puppets (wayang kulit), temple relief and modern drawing, animated images, films and pictures produced by other digital technologies, such as an images [6].

Japanese animation has become an industry and culture that popular throughout the world. In Japan, anime is a very important means of communication. It is considered to be one of the most innovative and responsive sectors of the media [7]. Even now, animation became the reason for most Japanese learners to learn Japanese. The images displayed in Japanese animation or cartoons have a naturalistic style and can realize dynamic integration between Japanese culture and foreign culture. The interesting stories and pictures make Japanese animation popular so that a lot of people use animation as teaching material or research material.

Visual Language that used by the West is NPM (Natularis-Perspektip-Moment opname), where object is described one direction, one place and one time or can be called still picture or images that do not tell stories. It was first known during the Renaissance era, which the images depict a perfection; for example, a perfect body is a proportional and athletic one [8].

In addition to NPM, there is a visual language that began to be found Tabrani namely RWD (flat time space). RWD is a visual language that has a time dimension and tends to ignore the dimensions of space so that it is more narrative / storytelling [3]. Animations in the world commonly use NPM, but Japanese is different. They use RWD visual language in animation frames

In this study the authors are interested in researching images in anime seen from visual language theories. Therefore in this study the question research are what kind of visual language that appear in Japanese anime and how it is displayed.

\section{METHOD}

The research approach used a qualitative approach because in this study will explain the results of observations that will be described descriptively. The research method used is descriptive qualitative research. The animated images used in this study are a few frames of the famous animation One Piece episode 809 by Toei Animation.

One Piece tells about a group of pirates led by Monkey D. Luffy and goes looking for the treasure of the pirate Gol D. Roger, One Piece. Luffy became a rubber man who had the strength to lengthen his body after accidentally eating the 
fruit of Gomu Gomu, one of the devil's fruits. During the trip Luffy met many new friends and diverse enemies.

\section{RESULTS \& DISCUSSION}

This study took the case of visual language in the One Piece ep 809 anime series in every frame found in many visual languages. In visual language, there are terms that are used, among others: wimba, the contents of wimba, the way of wimba, the procedure of expressions in and outward expressions. Imaji is referred to as wimba. The contents of the wimba are objects drawn. The way the wimba is the way objects are drawn. The order of expression is a way of compiling various contents of wimba and the way of wimbanya so that a single picture can tell stories. While the outer expression is a series of single images with the next one until a series of images can tell stories. Here are the results of the analysis of visual language in the animation. Here are the frame scenes that ware taken from the anime.

\section{A. $1^{\text {st }}$ Scene}

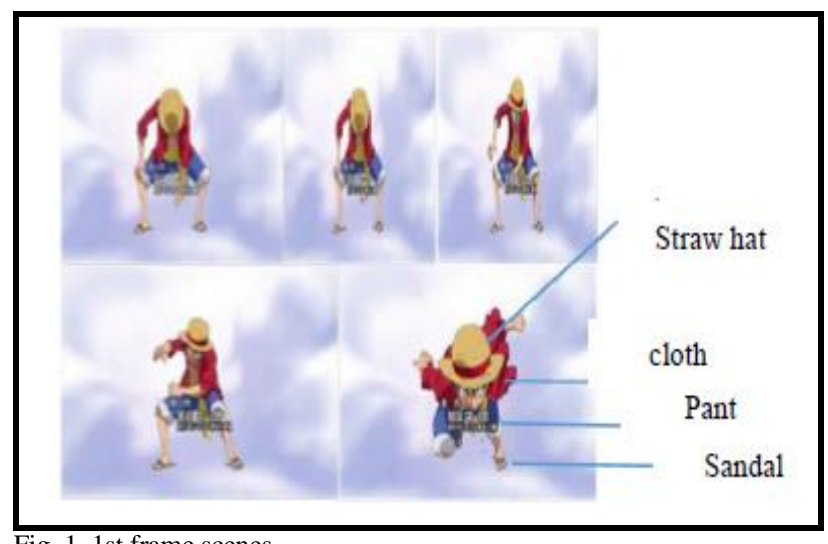

Fig. 1. 1st frame scenes

\section{Picture's story}

Monkey D. Luffy, his nicknamed is Straw Hat Luffy . He is a Pirate captain and taking a part as protagonist. At the beginning of the series, he accidentally ate the devil fruit type paramecia Gomu Gomu no Mi, thus making his body obtain high flexural rubber properties. After his life was saved by Shanks when he was seven years old, Luffy decided to have the same dream as Shanks, which was to find a legendary treasure and replace Gold Roger as the Pirate King. Ten years later, using Shanks' straw hat, he sailed into the ocean to get a crew and sail the seas of the Grand Line, a place suspected of being a One Piece hideout.

\section{Visual languae from the $1^{\text {st }}$ scene}

In this scene, wimba is depicted with images from head to foot so that it can be easily recognized. The Wimba is portrayed from a reasonable angle, because it directly faces the viewer. On the head on the wimba is described as enlarged, because it is considered important. In the wimba it is seen moving from the start to get ready to slide forward.

TABLE.1 The ANALISYS OF VisUal LANGUAE IN SCENE Frame

\begin{tabular}{|c|l|c|}
\hline Way of Wimba & Way of Wimba & Analisys \\
\hline$\bullet$ From foot to head & $\bullet$ Enlarged & $\begin{array}{r}\text { The image in the image } \\
\text { can be recognized from }\end{array}$ \\
\hline
\end{tabular}

\begin{tabular}{|c|c|c|}
\hline $\begin{array}{l}\text { - Genesis } \\
\text { - Reasonable angle }\end{array}$ & $\begin{array}{l}\text { - Stylized } \\
\text { Naturalization } \\
\text { - Characteristics of } \\
\text { motion } \\
\text { - Shifted }\end{array}$ & $\begin{array}{l}\text { head to foot } \\
\text { - All bodies are seen } \\
\text { from a reasonable } \\
\text { angle } \\
\text { - In the head section of } \\
\text { the enlarged image }\end{array}$ \\
\hline
\end{tabular}

\section{B. $2^{\text {nd }}$ Frame}

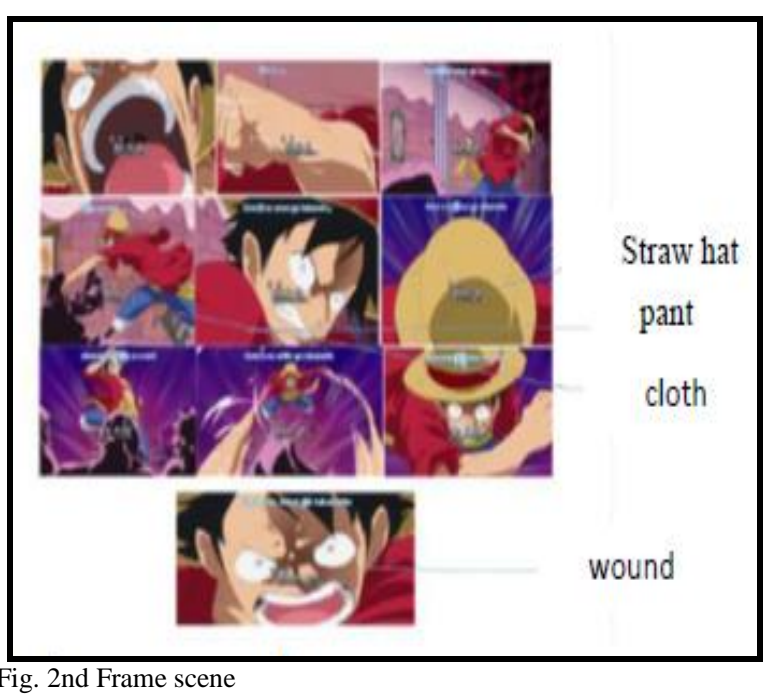

Story of the Pictures

Monkey D. Luffy, at the beginning of the series, accidentally ate the devil fruit type paramecia Gomu Gomu's fruit, thus making his body obtain high flexural rubber properties. After his life was saved by Shanks when he was seven years old, Luffy decided to have the same dream as Shanks to find a legendary treasure and replace Gold Roger as the Pirate King. Ten years later, using a straw hat on Shanks, he sailed into the ocean to get a crew and sail the seas of the Grand Line, a place suspected of being a One Piece hideout.

\section{Visual languae in $\mathbf{2}^{\text {nd }}$ frame scene}

In this scene, wimba is depicted with images from head to foot so that it can be easily recognized. The Wimba is portrayed from a reasonable angle, because it directly faces the viewer. On the head and hand part of the wimba is described as enlarged, because it is considered important. In the Wimba, it seems to move to hit the opponent quickly so that the hands look a lot and the hands extend.

TABLE 2. The ANALisys OF VisUAL LANGUAE IN SCENE FRAME 2

\begin{tabular}{|c|c|c|}
\hline Way of Wimba & Way of Wimba & Explanation \\
\hline $\begin{array}{l}\text { - From foot to head } \\
\text { - Genesis } \\
\text { - Reasonable angle }\end{array}$ & $\begin{array}{l}\bullet \text { Enlarged } \\
\bullet \text { Stylized naturalization } \\
\bullet \text { Characteristics of motion } \\
\bullet \text { Shifted }\end{array}$ & $\begin{array}{l}\text { - The image can be } \\
\text { recognized from } \\
\text { head to foot } \\
\text { - All bodies are seen } \\
\text { from a reasonable } \\
\text { angle } \\
\text { - The head has been }\end{array}$ \\
\hline
\end{tabular}




\begin{tabular}{|l|l|l|}
\hline & $\begin{array}{l}\text { enlarged } \\
\text { - Wimba is seen } \\
\text { moving hitting the } \\
\text { opponent quickly so } \\
\text { that the hands look } \\
\text { more than one and } \\
\text { extended } \\
\text { - Shifted from left to } \\
\text { right and forward to } \\
\text { back }\end{array}$ \\
\hline
\end{tabular}

\section{C. $3^{\text {rd }}$ Scene}

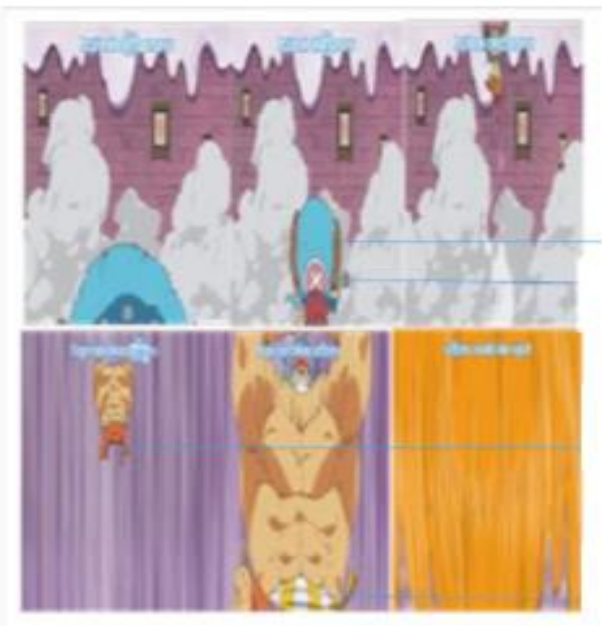

\section{Hat}

horn

pant

tyre

Fig.3 3rd Frame Scene

\section{Story of the Pictures}

Tony Tony Chopper is a doctor and a blue-nosed deer who gains human abilities after eating the devil's fruit zoan Hito Hito no Mi. Using a type of medicine that he developed himself, Rumble Ball, Chopper can transform into more than three basic forms derived from the ability of his devil fruit.

\section{Visual languae of the $3^{\text {rd }}$ scene frame}

The scene with wimba is depicted with images from head to foot so that it can be easily recognized. The Wimba is portrayed from a reasonable angle, because it directly faces the viewer. On the part of the body and there is a shrinking wimba it is described as enlarged, because it is considered important. In the Wimba Wimba it is seen moving to slash opponents quickly as flying ends with an X.

TABLE 3. THE ANALISYS OF VISUAL LANGUAE IN SCENE FRAME 3

\begin{tabular}{|l|l|l|}
\hline Way of Wimba & Way of Wimba & \multicolumn{1}{|c|}{ Explanation } \\
\hline $\begin{array}{l}\bullet \text { From foot to } \\
\text { head }\end{array}$ & $\bullet$ Inlarge & $\begin{array}{c}\bullet \text { Wimba in the image } \\
\text { can be recognize } \\
\text { from head to foot }\end{array}$ \\
$\bullet$ Natural angle & $\begin{array}{l}\text { Ntilasi } \\
\text { - Genesis } \\
\text { incident }\end{array}$ & $\begin{array}{l}\text { Hole body can be } \\
\text { seen from natural } \\
\text { angle }\end{array}$ \\
\hline
\end{tabular}

\begin{tabular}{|l|l|l|}
\hline & $\bullet$ Shifted & $\begin{array}{l}\bullet \text { Part of the body is } \\
\text { being inlarge }\end{array}$ \\
& $\begin{array}{l}\text { - Wimba looks like } \\
\text { jumping up and the } \\
\text { body change from } \\
\text { small to big size. }\end{array}$ \\
\hline
\end{tabular}

\section{CONCLUSION}

We live in the visual world and we spend a lot of energy feeling and physical energy in seeing things. This Wimbas help us in forming perceptions about the world in which we are. We communicate through Wimba. Visual communication is a central aspect of our lives, where we use the senses more often than other senses. Most visual communication can occur directly, both through symbols, so that every scene in a 2-dimensional animation can freely express both pleasure, anger, confusion, love and others. Most of the ways in Wimba in Japanese animation are reduced and enlarged one indicate important things. The main hero position is usually in the middle, there are also positions from left and right or from left to right. The Genesis method in one piece anime is arranged so that the audience does not feel bored. This is because Wimba is a part that fills up space and time in the anime frame with a short time. Every time a scene appears, followed by the emergence of new things and maybe just then we can catch it in plain view.

\section{REFERENCES}

(1) Malcolm D John, 1986.Visual Lnguage: The concept and Application in th Classroom. https://www.uleth.ca/dspace/bitstream/handle/10133/1009/Malcolm_J ohn_D.pdf?sequence=1\&isAllowed=y

(2) Erwig, Smeltzer \&Wang. 2016. What is Visual Language? https://web.engr.oregonstate.edu/ erwig/papers/WhatIsaVL_JVLC17. pdf

(3) Tabrani, 2005. Visual language. Kelir Pustaka. BandungBIBLIOGRAPHY

(4) Suardana, 2006. Metode Pembelajaran Penelitian dan Penilaian Seni Rupa dari Aspek Cara Wimba. http://eprints.uny.ac.id/4088/2/Metode_Pembel_Penilaian_SR_ISI_De npasar\%28Jurnal_SR\%29.pdf

(5) Wakhyudin \& Rofian, 2017. Kajian Estetis Bahasa Rupa Ilustrasi Buku Tematik Terpadu Kurikulum 2013 Untuk Kelas 1 Sekolah Dasar (Tema 6: Lingkungan Bersih, Sehat, Dan Asri). http://journal.upgris.ac.id/index.php/malihpeddas

(6) Tabrani, 2018. Pinsip-Prinsip Bahasa Rupa, Jurnal Budaya Nusantara Vol. 1 No. 2 Surabaya

(7) Feigenblatt, 2008. Understanding Japanese Animation. https://journal.vpweb.com/upload/4729608.pdf

(8) Iskandar \& Putri, 2014. The Importance of Visual Language In Learning
Photography http://repository.ut.ac.id/4938/1/The\%20Importance\%20of\%20Visual $\%$ 20Language \%20In\%20Learning\%20Photography.pdf 